\title{
The world and Europe in the eyes of Turkish undergraduate students
}

Le monde et l'Europe vus par les étudiants turcs de l'enseignement supérieur

\section{France Guérin-Pace, Etienne Toureille and Claude Grasland}

\section{(2) OpenEdition}

\section{Journals}

\section{Electronic version}

URL: http://journals.openedition.org/belgeo/15026

DOI: $10.4000 /$ belgeo.15026

ISSN: 2294-9135

\section{Publisher:}

National Committee of Geography of Belgium, Société Royale Belge de Géographie

\section{Electronic reference}

France Guérin-Pace, Etienne Toureille and Claude Grasland, «The world and Europe in the eyes of Turkish undergraduate students », Belgeo [Online], 4 | 2014, Online since 20 December 2014, connection on 30 April 2019. URL : http://journals.openedition.org/belgeo/15026 ; DOI : 10.4000/ belgeo. 15026

This text was automatically generated on 30 April 2019.

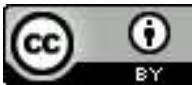

Belgeo est mis à disposition selon les termes de la licence Creative Commons Attribution 4.0 International. 


\section{The world and Europe in the eyes of Turkish undergraduate students}

Le monde et l'Europe vus par les étudiants turcs de l'enseignement supérieur

France Guérin-Pace, Etienne Toureille and Claude Grasland

The authors would like to express their gratitude to the Turkish colleagues from Attatürk University (Erzurum), Istanbul University (Istanbul) and Dokuz Eylül Üniversity (Izmir), who realized the survey in Turkey: Pelin Bingol, Hamdi Emeç, Nihal Kırkpinar-Acar, Burcu KumbulGüler, and Oğul Zengingönül.

\section{Foreword}

1 The EuroBroadMap research project (2009-2011) has been an exceptional opportunity to benchmark the vision of the world of undergraduate students around the world (43 cities in 18 different countries). The cross-synthesis of the global results, which were recently published by the coordinators, has demonstrated that important theoretical results could be derived from the project concerning the concept of mental mapping as well as political recommendations as regards the image of EU/Europe in the World (Didelon-Loiseau \& Grasland, 2014).

2 These results, based on the complete sample of countries, have been drawn from an indepth analysis of each national situation conducted by researchers from all participating teams. A synthetic and interactive document called Country Synthesis Report (Grasland, 2011) has been produced, which shows for 12 countries the mental maps of Europe and the World, as well as various explanatory factors like migration or trade ${ }^{1}$. This comparative effort from each team slowed down a more detailed analysis of the internal specificities of the political visions expressed by students in each country, despite some cross-analyses of sub-samples, like the BRIC countries (Kolossov, 2013).

3 A first objective of the present paper consists in filling this gap as regards Turkey, as it has recently been done for Tunisia (Bennasr \& Grasland, 2014). These two countries are 
particularly interesting because they appear especially complex in terms of internal and external perception. In the classification of attractive and repulsive countries based on the survey EuroBroadMap², they belong to a very specific type of "Ambiguous liked/ disliked countries [that] are characterized by opposite levels of attractiveness and strong variations of knowledge according to the places of survey. For example, Turkey is mentioned by the students from the EU countries as a place where they would not like to live, but it is the opposite for students from Egypt and Tunisia (the survey took place two years before the 'Arab Spring' of 2011). The same was found for South Africa" (DidelonLoiseau \& Grasland, 2014).

4 In the second part we will provide a more detailed analysis of the internal variations of Turkish students' perception of the world and Europe by gender, location and field of study, complementing the work performed by the Turkish researchers involved in the EuroBroadMap project (Kirkpinar-Acar et al., 2011).

\section{Introduction}

5 Recently, Turkey has attracted interest because of its relatively good economic health in a context of economic crisis in Western Europe, with an impressive economic growth index in the 2010s ( $8 \%$ in $\left.2010^{3}\right)$. At the same time Turkey has become part of the "G20" as the $17^{\text {th }}$ richest country by GDP. Like India, Brazil, Russia, South Africa and Argentina, this country of 76 million people ${ }^{4}$ with a GDP of $\$ 789$ billion might be seen as an "emerging power" (Bazin et al., 2012) at the gate of Europe and a "new actor" in the global geoeconomic game (Nahavandi, 2012).

Major changes in the region, like the end of the bipolar world in the 1990s and the shrinking of the Russian empire, allowed new opportunities for Turkey in its neighbourhood, after more than 70 years of Soviet domination over Caucasian and Central Asian countries. More recently the gradual withdrawal of the United States from the Middle East, the EU's political and economic difficulties and the diplomatic isolation of regional competitors, like Iran, gave space for Turkey to rise as a regional power.

7 Strengthened by its economic situation, this restructuration of the geopolitical context converges with historical advantages in countries like Azerbaijan and Turkmenistan, which share historical background and cultural relations with Turkey. It gives an opportunity to take advantage of Turkey's strategic situation "between three worlds" (Bazin et al., 2000): the heritage of its situation in the core of the Ottoman Empire, stretching from the Middle East to the Caucasian Area and Europe (Balkans). This point is even more important if we take into consideration the development of a multidimensional Turkish foreign policy and the re-development of its diplomatic relations with its eastern and southern neighbours in the past decade, especially through the action of the former Turkish foreign minister Ahmet Davutoğlu ${ }^{5}$ (Robins, 2007; Groc, 2011; Navahandi, 2012; Artık, 2013).

8 These considerations reinforce the necessity to escape from a Eurocentric perspective, which considers the European Union as the sole horizon for Turkey in the near future. The heritage of long-term Turkish history is built on a multi-oriented policy and national iconography, which explain why Turkey takes part in various partnerships, like the Organisation of the Black Sea Economic Cooperation and the Organisation of Islamic Cooperation, while taking part to the European integration process. 
But in spite of these developments, a short look at the economic situation of Turkey relative to its neighbourhood leads us to downplay its situation as an emerging pole. In 2010, when economic growth was at its highest, "the major trading partners of Turkey are located in its immediate neighbourhood, including Russia, as well as in Western Europe. In contrast, other major economic powers, notably the USA, have limited trade relations with Turkey. We can observe that Turkey has a negative balance with regard to manufacturing medium- and high-technology goods with all major developed areas, but especially with East Asian economic powers." (Kırkpınar-Acar et al., 2011). Turkey could also be seen as a semi-periphery of the European centre, according to Wallerstein's definitions (Wallerstein, 2009). At the same time, Turkey's situation with regard to its international relations and classic geopolitics gives it the aspect of a "shatterbelt". In a general definition ("a geographic region that is plagued both by local conflicts within or between states in the region, and by the involvement of competing major powers from outside the region" - Hensel et al., 1994), its status of strategic ally of Western powers (NATO) confers upon Turkey the role of outpost on the Middle East and the Russian buffer zone. The Turkish situation, between Europe, Middle East and the Russian centre, could also be interpreted in a wider definition of shatterbelt: a region influenced by different external forces, a crossing-point situation and a strong influence of long-term history (Rey, 1996).

In other words, considering Turkey as an emerging power is not self-evident, especially regarding its general economic and geostrategic position in history. In this paper we deal with these questions of centrality and polarisation in terms of people's representations. Our postulate is that the way to understand the world is not purely conditioned by economic or diplomatic considerations. Indeed, even if, according to the trade balance, Turkey is dominated by the European centre, Turkish people may not be influenced by these considerations and perceive the world independently from this European influence. The way of thinking which promotes the idea of Turkey as a great power (Artık, 2013), emphasised by Turkish government leaders and the media, has as many arguments going for it in the sense of an autonomous perception of the world according to Turkish public opinion.

11 This paper aims to evaluate how Europe and the world are perceived by Turkish undergraduate students by using secondary data of a worldwide survey carried out in 2009 by the FP7 EuroBroadmap project. The paper consists of four parts:

1. Discussion of the hypothesis of a polarisation of Turkish representation by the European Union against the alternative hypothesis of a dual vision of Europe related to the ambiguity of Turkey's situation.

2. Presentation of data and methods used to evaluate Turkish students' dominant representations of the world.

3. Presentation of empirical results concerning Turkish students' mental maps in terms of knowledge and attractiveness of world countries and evaluation of the specific place of Europe.

4. Discussion of the limitations of the aggregated results and exploration of the variation of mental mapping according to place of survey, gender or field of study.

5. Conclusion and prospects for further researches. 


\section{A structural shift in Turkey's self-perception with respect to Europe and the world?}

12 To answer the question: "How Turkey perceives itself in the world", we first develop a classic geographical dialectic by searching for the places that polarise Turkish representations. The difficulties in classifying Turkey as a semi-periphery, shatterbelt, or emerging power - in other terms as a centre under influence or as an autonomous/ original producer of interpretations or representations of the world - are an interesting grid of analysis for understanding how Turkish people currently perceive their place in the world and in the regional neighbourhood.

In the Turkish regional context, the most important pole should apparently be Europe, because of its influence on the functional integration of Turkey in the common market and its involvement in the process of political regionalisation, with an early involvement in the European political integration process: the European Union (EU) and its antecedents (Turkey's first request for an association with the European Economic Community - EEC - was in 1959, signed in 1963).

Is there some kind of empowerment of Turkey compared to Europe? Is the Turkish way of seeing the world influenced by the European way of seeing it? Are they converging or is this shatterbelt situation between "three worlds" a factor for the production of original discourse about the world?

Coming back to our question about the polarisation of Turkish representations, selfreliance of the Turkish point of view, could also be seen in the representation of a weak attractiveness of a hypothetical European pole (after all, it is also possible that there is a European pole in Turkish minds) This loss of influence of Europe could have two different (but not exclusive) manifestations:

- a diversification of attractive horizons in favour of alternative centres (BRICS, Gulf States, North America, etc.). This configuration would downplay a monolithic orientation of worldwide representations from the Turkish point of view;

- a limitation of the polarisation to its close neighbourhood. This attractiveness restricted to a limited area is another way of identifying the originality in the Turkish way of seeing the world. It could also lead to identifying a kind of "Turkish region" in people's minds, which could be related to cultural and historical heritages, for instance by integrating Middle Eastern or Caucasian countries in a "greater Turkestan".

\section{Data and methods: a survey based on undergraduate students' mental maps}

In this paper we focus on the specific case of Europe, perceived in a wider definition than the EU from the point of view of the Turkish population. To that aim, we examine a corpus of answers in terms of subjective perception of the world, through a geography of the perception of the world. To grasp a Turkey-centred geography of the world, we chose to place our study in the field of representations studies, which is a large and diversified field in geography. representations: opened-ended questions, interviews, blank map and mental maps. These 
methods have long been used in these fields to understand the relationship of individuals to their environment. Social representations are usually defined as a set of knowledge and beliefs about objects and concepts which help us to cope with the world around us (Dortier, 2002). The concept of mental maps emerged in the 1960s from the encounter between spatial psychology and geography. Psychologists generally focused on the notion of cognitive space with the hypothesis that space is full of meanings and values. Geographers tend to focus on the analysis of the links between representations of space and spatial behaviour and practice (Lynch, 1960; Saarinen, 1987; Gould et al., 1974). Both fields refer to the theory of "man's shell" (Moles and Rohmer, 1978), a series of circles around individuals that define their level of knowledge of different places: closer spaces are the best known. The mental maps concept raises some issues that underline the theoretical model implemented in the EuroBroadMap project. Those issues address the individual/collective representations duo and involve both space (distance from the object) and time (individual and collective times of both heritages and perspectives).

The EuroBroadMap survey consists of a self-administered questionnaire with a limited response time ${ }^{6}$. It combines a set of questions, including open-ended questions and a blank map on which the students had to draw their perception of the limits of Europe and associated words (Brennetot et al., 2013). This paper focuses on the part of the questionnaire dealing with the perception of places (countries and cities) as attractive ones or not for living.

19 One way of understanding the relationship of individuals to their environment consists of asking questions about the attractiveness of places (Gould et al., 1974 ; Guérin-Pace, 2006b). We chose this approach in order to draw a map of the relatively important places in the world according to the Turkish point of view. In that sense our objective was not to collect information about "exact" places to move to but more subjective information which belongs to imaginary geographies.

20 Two questions were introduced in the questionnaire to get an evaluation of places in term of attractiveness: "Apart from your country7, where would you like to live in the near future?" (a way of encouraging the students to give credible information in the formulation of this hypothetical situation), and the opposite question: "Apart from your own country, where would you not like to live in the near future?". The question was repeated with cities instead of countries. ${ }^{8}$ The word "place" was too broad a notion for the general question about "living" preferences, which is why it was necessary to specify it (to avoid non-locatable spatial entities - "in the Quartier Latin", the risk of non identifiable places - "with my family" -, or in general, conceptualised or type ideal entities - "in the mountains" Guérin-Pace, 2006a).

21 The reason for combining different scales of places in the questionnaire is based on the premise that these kinds of spatial entities arouse two different grids of interpretation of space (Jessop et al., 2008). A clue to this could be found in the fact that the results in terms of cities are less rich than those in terms of countries: it seems to be more difficult for students to identify cities (especially in a negative way, Grasland et al., 2011). That is not surprising when we think about the extent of dissemination of "world political maps" representing the states by a puzzle of inter-state borders, especially in the school geography. For this reason, this paper only deals with the results at state scale in relation to individual socio-demographic characteristics ${ }^{9}$ collected in the survey. "would like to live in the near future" is based on the observation that people do not 
answer according to the same pattern of references when the question is about a place in the future as for other represented places like place of belonging, place of attachment, etc. (Guérin-Pace, 2006b). The same observations also show that young subjects, especially students, are very receptive to this kind of question. This choice is also more relevant in our case because a question in terms of place for the future is "more disconnected from the trajectory" of people who can give information about abroad ${ }^{10}$ ( Ibid.).

\section{University undergraduate students as potential leaders of tomorrow's Turkey}

To study this question we chose to work on a specific population group among Turks: students. We seek to draw up a picture of the geography of the world in progress. Therefore gathering representations from a young population, theoretically less dependent on past representations, seems to be appropriate, in addition to the fact that they are in a transitional period of their life cycle (before entering the job market, more able to formulate plans - Didelon et al., 2011). Relative to other segments of the population, "academic people are probably more aware than others of the existence of 'the rest of the world' as they live in a highly inter-connected era in terms of information flows and media (television, Internet) and therefore more likely to have an enhanced consciousness of the rest of the world compared with previous generations, and not only a knowledge of the rest of the world but also a point of view about it" (Ibid.).

It is also a relevant choice considering Turkey's demographic situation: a country which completed its demographic transition in the early 2000s (Behar, 2002) and therefore a young country compared to the European ones (in 2010 almost half the population in Turkey was under $25^{11}$ ). A consequence of the large number of young people in the country is also the increase in the student population. So focusing the analysis on a young population is of interest because of the size of this group in Turkey, and they have the advantage of being easily identifiable.

The second argument is more related to a prospective attitude concerning their future in a liberal democratic system. Bearing in mind that we are studying a population around 21 years old in 2008, one may suppose that some part of this educated population (an elite?), might be the upcoming leaders of Turkey, or at least the active forces of the country in the next ten or twenty years. So this research could be a way of producing information about the state of mind of the Turkey in the next decades. In the game of competition between countries and universities for attracting a type of migrants that the European Union would welcome, it might give interesting information complementing other surveys, specifically dealing with attractiveness to students and the so-called "knowledge economy " (ACA, 2004).

Finally, choosing to study the perception of an elite might be an accurate way of avoiding the position that considers negative perceptions of foreign countries or of Europe as specific to the "rural, non-urbanised and non-educated population" (Yerasimos, 2005). 


\section{Constructing a geography of the world according to Turkish students}

First of all, even if students are an identifiable group, with specific demographical characteristics and practices, they are not a homogeneous population. The factors of variation are various (socio-demographic parameters, academic backgrounds, geographical path, etc.). In particular, it has been noticed that for the same social characteristics, mental maps strongly depend on the location of the place of survey (Saarinen and MacCabe, 1995). Regarding the Turkish geographical context, it was especially important to examine these geographical variations, in relation to the strong development gradient between the East and West of Turkey, documented among other by Hütteroth (Hütteroth, 1982; Bazin, 1995). Therefore the survey was not conducted only in big western cities (Izmir, the third city in the country, and Istanbul with 13.5 million people ${ }^{12}$ ) but also with students from the "far eastern" Anatolian city, Erzurum (about 500,000 inhabitants $\left.{ }^{13}\right)$, located approximately 200 kilometres from the Iranian border.

Another important hypothesis for understanding the student's representations is to establish a link between the knowledge and individual background provided by the family and that provided by the academic context (school and university). For this, we selected in the sample students issued from varying fields of study: business administration, engineering, health, political sciences, and social sciences. About 10,000 undergraduate students around the world were questioned between 2009 and 2012. The global aim of the project was to collect a set of visions of Europe from abroad, with a specific interest given to the close neighbourhoods of Europe (Didelon et al., 2011) ${ }^{14}$. In Turkey, the survey was given to 734 students of these 5 fields of study, in 3 cities (Istanbul, Izmir, Erzurum) during winter 2009-2010 (see Table 1).

Table 1. The Turkish sample of the EuroBroadmap Survey.

\begin{tabular}{|ll|ll|}
\hline Cities of survey & Fields of study & \\
\hline Erzurum & 238 & Art & 116 \\
Istanbul & 251 & Business & 120 \\
Izmir & 245 & Engineering & 132 \\
& & Health & 120 \\
& & Political Sc. & 119 \\
& & Social Sc. & 127 \\
\hline Total & \multicolumn{3}{|l}{} \\
\hline
\end{tabular}

SOURCE: EUROBROADMAP, 2010

\section{Main results: knowledge and attractiveness of the world's countries for Turkish students}

The Turkish team of the EuroBroadMap project collected 734 answers from students located in the three cities. A total of 664 students answered the question of attractiveness and mentioned 3,400 places located in 187 different countries. A summary map in the form of a cartogram (anamorphic map) shows the most frequently mentioned countries 
(area size) and indicates which type of student opinion dominates (attraction in dark grey, repulsion in light grey, balanced opinion in medium grey).

Figure 1. Knowledge and attractiveness of the world's countries for 692 Turkish undergraduate students in 2009.

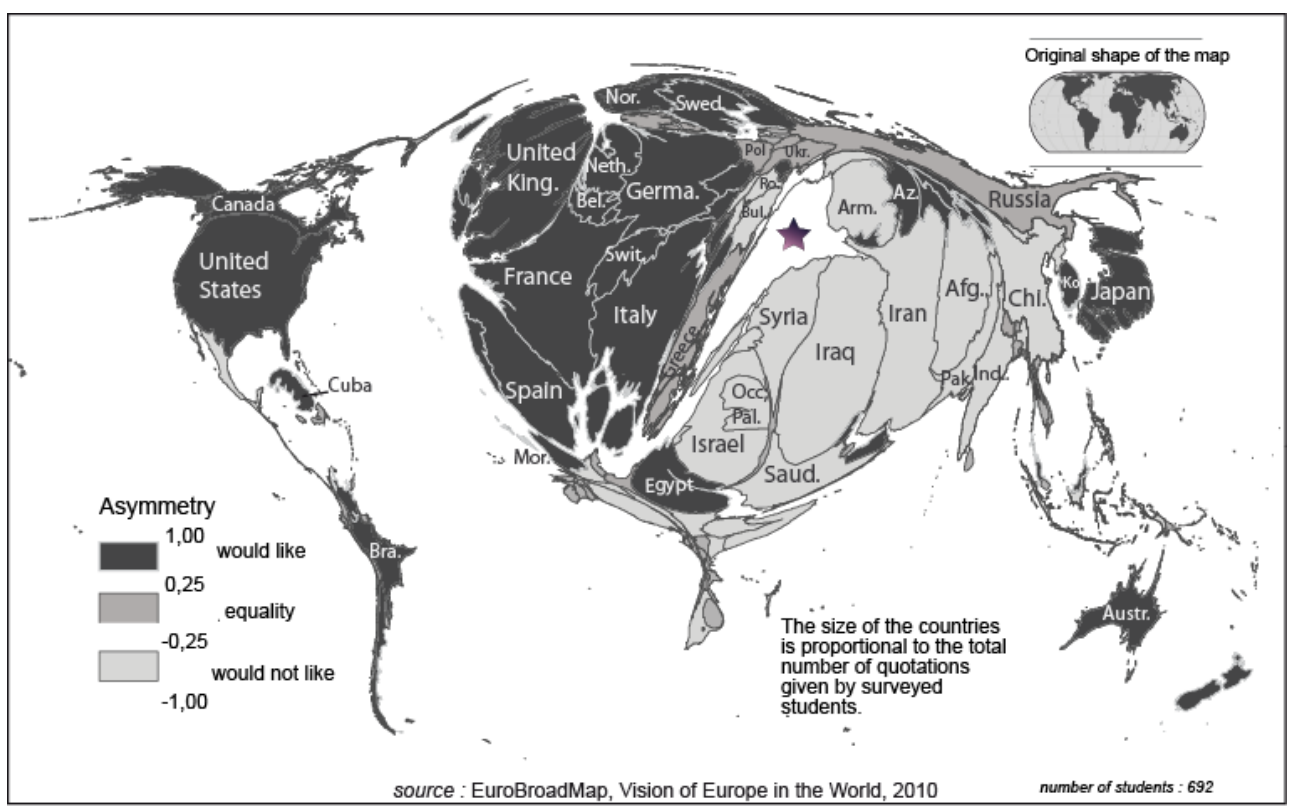

Source: adapted from Kırkpınar-Acar et al. 2011

The positive choices of students are commented as following: "According to the results of the survey in Turkey, the most frequently mentioned positively perceived countries are Italy, the UK, France, Spain and Germany, which are all located in Western Europe. It is possible to argue that the positive perceptions held by Turkish students of Western Europe are in line with the foreign policy of Turkey. Turkey has always preferred to be Western-oriented in its foreign policy since its establishment. Thus, Turkish students' choices are appropriate for Turkish foreign policy. In addition, it can also be seen that there is no direct correlation between positively perceived countries and countries which Turkish students have visited: the most commonly visited countries are Germany, Azerbaijan, the USA and France" (Kırkpınar-Acar et al., 2011). Concerning the negative choices: "Syria, Armenia, Iraq, Afghanistan, Israel and Iran are the countries in which Turkish students declare that they would least like to live. These negative perceptions can be explained by the ongoing conflicts, turmoil and wars in the regions in which these countries are located. These states have also faced common development and transitional problems, such as an unwillingness to democratize, weakness regarding human rights, Islamic religious fundamentalism, a lack of reforms to the market economy, a deficient work and investment environment, an unjust income distribution and difficulty integrating into the world economy. As these conditions are well-known by Turkish students, it is understandable for Turkish students to have negative perceptions of these Middle Eastern countries." (Ibid.)

31 Although it is quite easy to propose ad hoc explanations of the factors of attractiveness and repulsion of countries, it is more difficult when countries appear both attractive and unattractive. This is the case for the USA and Russia: "The USA and Russia are among the countries in which Turkish students would both like to live and not like to live. As Turkey 
has had economic, political, social and cultural relations with these two countries since its establishment, they were mentioned by most of the students. Negative or positive perceptions of Russia and the USA may depend on the students' political views. While more liberal or capitalist students would like to live in the USA, more socialist students would prefer to live in Russia" (Ibid.).

What is more interesting now is to examine jointly rather than separately the positive and negative opinions provided by students about countries.

\section{"Knowledge" versus "attractiveness": what are the poles of Turkish world representations?}

For this, two indicators are used. The first, called indicator of "knowledge" corresponds to the total number of mentions, whether positive or negative, for a given country, weighted by the total of answers (Grasland et al., 2011). The value ranges from 0 (no students mentioned a country) to 1 (all the students mentioned the country). To take into account the fact that a country is positively or negatively perceived by the students, we used a classical asymmetry index ("attractiveness"). ${ }^{15}$

$$
\begin{aligned}
& \text { Knowledge }\left(\text { country i) }=\frac{p_{i}+n_{i}}{S}\right. \\
& \text { Asymmetry (country i) }=\frac{p n_{i}-n_{i}}{p_{i}+n_{i}}
\end{aligned}
$$

Where $p_{i}=$ number of positive answers for the country $i, n_{i}=$ number of negative answers, and

$\mathrm{S}=$ number of students who answered to the question. 
Figure 2. Evaluation and "knowledge" of countries by all Turkish students: dominant representations of the world.

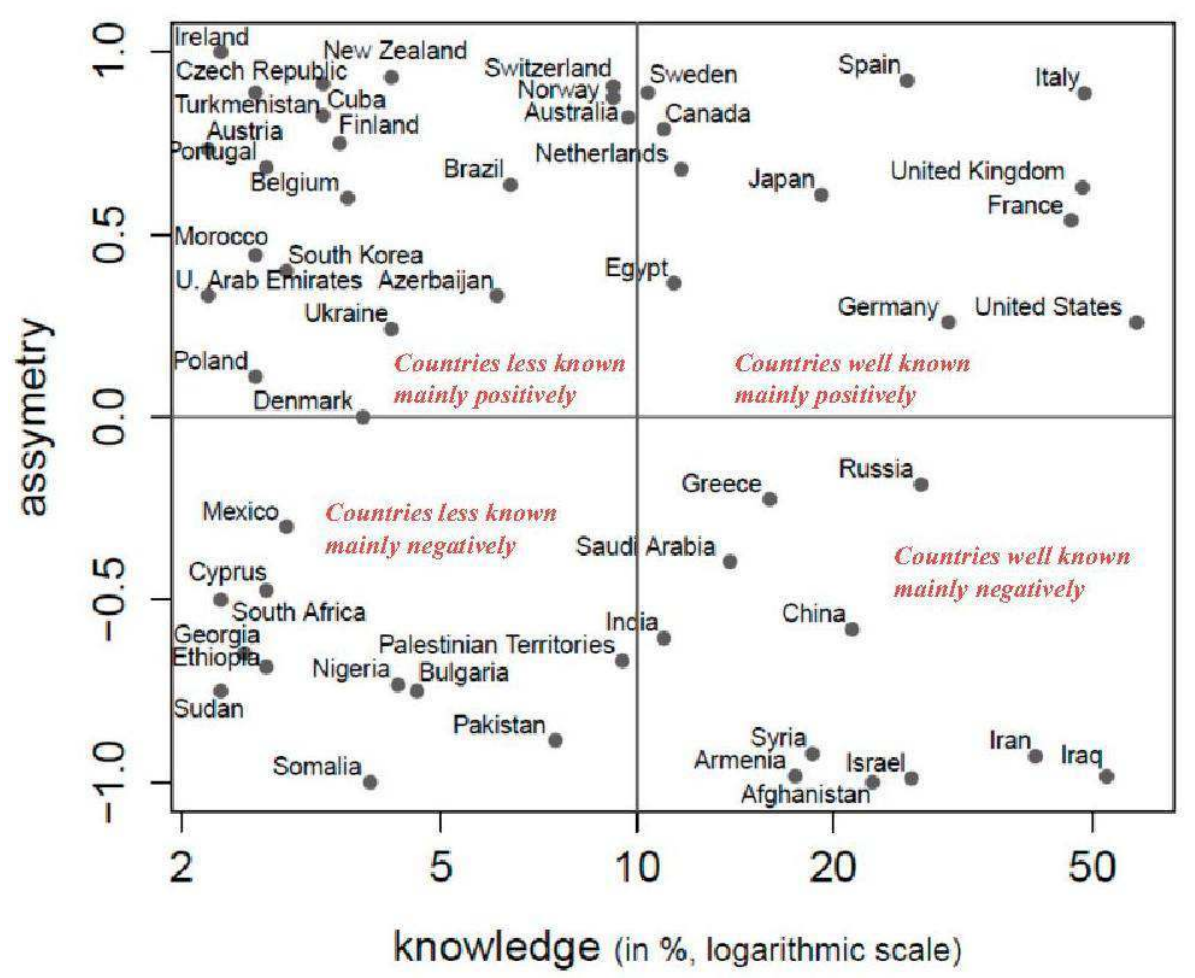

Source: Eurobroadmap, 2009

The combination of the two criteria reveals a more complex and subtle situation than the binary opposition between attractive and unattractive countries. Dividing the diagram into four quadrants, we can firstly identify well known and attractive countries (high indicators of knowledge and asymmetry) against well-known and unattractive countries (high knowledge, low asymmetry). But we have also to consider the case of countries that are attractive but less mentioned (high asymmetry, low knowledge) or unattractive but less mentioned (low asymmetry, low knowledge. But quadrants remain too categorical an approach and what is of great interest is to compare the position horizontally and vertically. For example, USA, Germany and Egypt are characterised by the same level of "balanced attractiveness", but with a clear hierarchy of knowledge. China, India and South Africa present the same level of "balanced repulsion" but are also very heterogeneous in terms of frequency of mention.

Looking at the data on student's migration from Turkey, those results are convergent. The destinations more often chosen by students in the survey are at the same time positively viewed in their representation as good places of life. However, we can mention few countries, like Spain, Egypt and Brazil, which are often quoted in a positive way but where the number of students welcome in 2009 is very low (less than 100 students). For Spain and Egypt, economic and political context have doubtless played a role while the image of the countries remained positive. For Brazil, maybe few opportunities to study there but a positive vision of the country could explain the gap. On the opposite, some countries appear to be important destinations of students while their perceptions from 
the students are predominantly negative, like Greece, Russia or Saudi Arabia or Bulgaria, in connection with the opportunities offered by these countries.

Table 2. Destinations of Turkish tertiary-level students in 2009.

\begin{tabular}{|c|c|}
\hline United States of America & 13045 \\
\hline Germany & 11279 \\
\hline Azerbaijan & 4010 \\
\hline Bulgaria & 3488 \\
\hline United Kingdom of Great Britain and Northern Ireland & 2683 \\
\hline Austria & 2616 \\
\hline France & 2330 \\
\hline Kyrgyzstan & 1119 \\
\hline Ukraine & 1024 \\
\hline Italy & 614 \\
\hline Canada & 591 \\
\hline Switzerland & 561 \\
\hline Australia & 410 \\
\hline Kazakhstan & 409 \\
\hline Russian Federation & 400 \\
\hline Sweden & 365 \\
\hline Netherlands & 197 \\
\hline Romania & 184 \\
\hline Hungary & 168 \\
\hline Japan & 165 \\
\hline Republic of Moldova & 149 \\
\hline
\end{tabular}

Source : Unesco 2009 "Global Flow of Tertiary-Level Students", data available on: www.uis.unesco.org

In Turkey as in the majority of countries analysed in the EurobroadMap project, we observe that the degree of knowledge of countries is governed by a kind of gravity law, that is, the mention of countries is related to the size of countries and distance between them. Positively or negatively, students are more likely to mention a country that is 
either big or near (and if possible both). Positive appreciations are also conventionally related to economic prosperity whereas negative appreciations are frequently associated with poverty or countries at war. The application of these general rules to Turkey suggests that the attraction of western EU countries does not necessarily reveal a specific preference but simply the fact that it is the nearest richer economic pole. Despite the points developed in the first part of this paper, in the sense of a decrease in interest in Europe, European countries still remain attractive. In that sense, the Turkish vision of the world seems to be mainly polarised by the European centre via massive attractiveness and some western and southern European countries.

\section{Beyond the gravity model explanation: the specific features of the Turkish point of view}

But gravity laws do not explain all the differences and some observed on the diagram require a deeper analysis. The attractiveness of Europe appears high, especially for western-Mediterranean countries (Spain, Italy and France) and the western economic centre of Europe (France and Britain). East and central Europe are missing relative to these western European countries. The attractive centres of Europe are also at first concentrated in a limited number of western countries. When students are asked ${ }^{16}$ about the reasons for Italy and Spain's attractiveness they give first climatic and cultural explanations. According to these students, Southern European countries seem more attractive because of their climate and sharing with Turkey a "Mediterranean way of life", in comparison with Northern countries (Germany, Britain and France).

Concerning the specific features of Turkish perception, we notice that countries like Kazakhstan, Turkmenistan, Azerbaijan and Ukraine are seen positively by Turkish students conversely to students from other countries who mention them in a negative way. The fact that central Asian countries are viewed more positively by Turkish students (to a lesser extent Azerbaijan) can be explained by historical and cultural links between Turkey and these countries before their integration into the Soviet Union. As we mentioned, the importance of these ancient links between the various countries of the "Turkish world" is still emphasised in the Turkish school books (Copeaux, 1996, 2000). The fact that countries in the close environment of Turkey look very attractive raises the question of the possible emergence of an alternative to the European pole.

In a strip located in the middle of the graph, we notice a group of interesting countries with contrasted representations according to Turkish students. That is the situation of countries considered negatively and positively by a relative similar proportion of students. In this group, we find countries like the United States and Germany, with a weak positive dominance, and Greece and Russia, with a weak negative one. The most substantial case is the United States which is mentioned by 405 students over 734 Turkish students (59\%). We can explain the contrasted situation of United States (255 positive mentions against 150 negative ones) by the image of its global power and political model. Because of its importance in global politics and economy, United States can also at the same time be perceived positively with the American way of life and cultural productions (cinema, TV series, etc.), but as a hegemonic and imperialist power which contributes to the destabilisation of the close environment of Turkey, bearing in mind that Turkey shares a common border with Iran and Iraq and is still the recipient of major flows of refugees following the US invasion of Iraq in 2003. The case of Germany is quite similar, 
and can be partly related to the good knowledge of Germany in Turkish society, resulting from long-standing migration links and the existence of a transnational community. Even if this country is rich and relatively close to Turkey, the living conditions for Turkish migrants are very difficult and returning migrants are numerous. This migratory factor in favour of a high level of knowledge may also explain the case of France, Britain and of some Scandinavian countries, like Sweden.

41 The case of Russia can be interpreted in the same way as the United States: the perception of a powerful and hegemonic country, close to Turkey, which can at the same time be an attractive and alternative centre to Western Europe. The situation of Greece is more complex: about $40 \%$ of the Turkish students cite Greece as an attractive country ${ }^{17}$. We might have expected less attractiveness given the legacies of the traumatic Greek-Turkish history, but this is less surprising as we are looking at a young population.

All these observations confirm the fact that the polarisation of Turkish representations by a European pole is a complex issue. Excluding the first group of well-known and attractive countries, the perception of Europe is contrasted: most of Europe is viewed through a very limited number of countries (relative absence of eastern and central Europe in the mental maps) and some countries produce contrasted representations (United States, Germany). What about the negatively viewed countries? Do we find the same complexity in the polarisation of the mentions of negatively viewed places?

Apart from countries in a war context (the most negatively viewed) we find, in the bottom left quadrant of the graph, some authoritarian regimes (Iran, China, Saudi Arabia) and some sub-Saharan countries which can be seen as poor countries relative to Turkey (Somalia, Ethiopia, Sudan). We may emphasise the place of the two biggest Asian countries among the unattractive countries: China and India which are emergent countries. To a larger extent, except for Brazil, less mentioned, BRIC countries are well known but more often quoted in a negative way.

The negative perception of Israel is relatively surprising considering that the survey was carried out before the "Mavi Marmara Affair"18 (May 2010), while Israel was still an ally and an economic partner of Turkey. This may suggest a dissonance between diplomatic issues and the representation by the young educated population of a troublesome ally, considered as an occupying power in the complex game of the Middle East politics.

Among countries negatively viewed by Turkish students, we find other interesting cases of "memories of conflict". The case of Greece and Cyprus are easily understandable bearing in mind the common past between Greece and Turkey from the Greek-Turkish wars of the 1920s to the "remake of the oriental question" between these two countries with the Cyprus war in 1974. The negative perception of "Cyprus" refers to the Republic of (South) Cyprus as the north of the island is still recognised by Turkey and under its protection. Nevertheless, such a negative perception expressed by a young population, regarding to the improvement of the Greek-Turkish relations since twenty years (Akgönül, 2001), suggests a strong inertia of historical conflict in memories which can be compared to the negative perception of Germany expressed by French students. The same remark may be made for Armenia, located at the top of the list of unattractive countries (close to Afghanistan), more than 90 years after World War I. The negative perception of Denmark appears in a more contextual way and can be related to the cartoon scandal in autumn $2005^{19}$. 
So the negative perception of countries seems to be underpinned by more complex factors than for positively viewed ones. The main unattractive countries are concentrated in one of the most conflictual areas in the world, the Middle East and Central Asia, which is also close to Turkey. Negatively viewed countries are easy interpretable regarding to their political instability, conflict contexts or authoritarian regimes. Despite those elements, some countries reflect specific features of the Turkish historical or geographical context (Armenia), which are sometimes far from the extreme configurations described in the previous paragraph (Greece, Denmark). This last point shows that Turkey shares a complex relationship with some European countries like Greece, but also with a large part of its neighbourhood. This last point suggests that the emergence of a Turkish region is not self-evident, with the exception of the Caucasus area.

So far we have assumed that the representations of the students were consensual. If we now go deeper with this analysis, we realise that beyond the geographic differences several social and demographic factors play an important role in producing this subjective geography.

\section{Towards an individual geography of attractive and unattractive countries for Turkish students}

In this section we examine the importance of individual factors in the behaviour of students for choosing attractive or unattractive countries. For some students, their place of residence in Turkey seems to influence their choices, for others, gender or field of study, seems more determining. A multivariate analysis ${ }^{20}$ conducted on the sample of Turkish students identifies the socio-demographic factors that correlated most with the positive and negative mentions. In addition to geographical location, the demographic variable which is most significant is related to gender while the field of study is also a determining variable of perceptions. For each of these variables (place, study and gender), we used a method taken from the field of textual statistics (Guérin-Pace, 1998) to calculate the specific vocabulary for each sub-group. This method is based on comparing the list of responses from a given subgroup selected by a variable value (gender, city of survey or field of studies), with all the responses given by the entire population (all students). A statistical test is then used to identify the words (in this case countries) significantly over- or under-represented for each subgroup ${ }^{21}$. We applied this method to both answers (where would you like to live in the near future/where would you not like to live in the near future) in order to produce the countries' profiles in two dimensions: correlations and under-representations in terms of negative and positive mentions.

\section{The influence of the city of residence: a focus on the students from Erzurum}

The place of survey is identified through the cities where the survey was conducted (Erzurum, Istanbul and Izmir). Between cities, the ways of citing attractive and unattractive countries are quite different, especially between students living in Istanbul and those from Erzurum. The next graph presents a focus on the case of students from 
Erzurum by showing the specific correlations between positive and negative mentions of countries.

Figure 4. Attractive and unattractive countries seen from Erzurum.

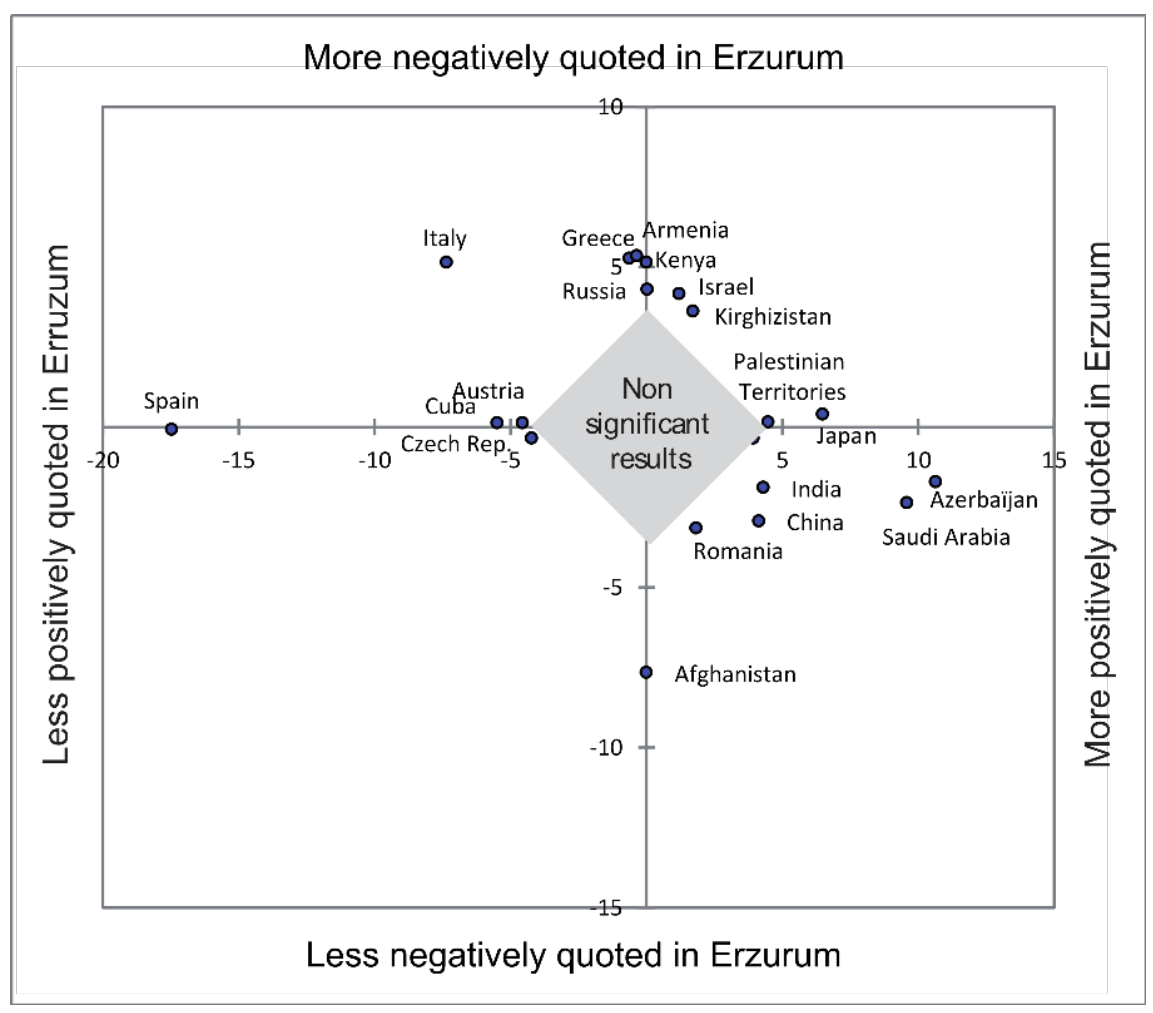

Source: Eurobroadmap, 2009.

How to read the diagram?

This matrix represents the countries significantly more or less mentioned by students from Erzurum as a place where they would like to live ("positively quoted", on the x-axis) and as a place where they would not like to live ("negatively quoted", on the y-axis). If a country is located on the right of the diagram, it means that this country is mentioned relatively more in a positive way by students from Erzurum. If a country is located on the left, the country is less often mentioned positively by students from Erzurum than by others in Turkey.

The same principle is adopted for the negative mentions on the ordinate: if a country is located above the horizontal axis, it is more often mentioned negatively by students from Erzurum; below less often mentioned negatively. Only significant differences on both axes (according to a $\chi^{2}$-test) are shown. For instance, Azerbaijan seems more attractive for Erzurum students (right of the diagram), but not significantly different from students of others cities according to negative mentions. Conversely, Spain is significantly less attractive for Erzurum students (right of the horizontal axis) but at the same time not seen more negatively. The case of Afghanistan shows a different situation: less often perceived as an unattractive country (negative side of the vertical axis) but not more often mentioned positively. 
This matrix of positive and negative perceptions gives some keys for interpreting two different kinds of representations, those which are consensually shared by the given population, in a positive or negative way, and those which are divergent, reflecting more differentiated views. For instance Japan is consensually viewed as an attractive country by Erzurum students while Greece and Armenia are negatively perceived as places to live relative to Istanbul and Izmir students. In a different way, opinion about Italy is more controversial: both considered as more unattractive and less attractive compared to other students.

Specific mentions by the students from Erzurum of the places where they would like to live show a West-East opposition. They are more positively attracted by countries located East (or South) of Turkey (Azerbaijan, Saudi Arabia, China, India, Japan and Palestinian Territories) while they less often positively mention western European countries like Spain, Austria, and the Czech Republic, to which may be added Cuba. Within this group, the Palestinian Territories and Japan are quite different, with an attractive perception not combined with a less negative one. In the case of Azerbaijan, Saudi Arabia, India and China, we have a more divergent configuration, because mentioning these countries more positively is combined with mentioning them less negatively.

According to this point, a first interpretation suggests that the location of Erzurum in the Turkish context may explain some elements of its specific representations, especially compared to the students of Istanbul, who significantly more often mention western countries as places where they would like to live ${ }^{22}$. Compared to Istanbul, the geographical distance to Azerbaijan makes it understandable to mention this country in a more positive way than Spain.

But the situation of Armenia, a country closer to Turkey than Azerbaijan and which is, on the contrary, more negatively mentioned, suggests that this geographical factor is not sufficient to explain the content of these representations. Moreover, students from Erzurum more often than others mention often positively eastern countries which have good diplomatic relations with Turkey (Azerbaijan). Other attractive Eastern countries for these students are also important economic centres like Japan, Saudi Arabia, India and China. These Eastern preferences may also be interpreted by their economic weight and prosperity in 2009 (students are choosing rich countries). But why do the students from Erzurum preferentially choose Eastern countries as places to live? Could a more metaphorical interpretation of the "Eastern" condition of Erzurum be relevant to explain this point?

In Turkey, Erzurum is currently seen by students as a part of the "Asian", "Eastern" or "Anatolian" side of Turkey as well as a less "modern" or more "conservative" place ${ }^{23}$. These elements are of course stereotypes, as in every process of external assignation of sub-national identities. However, in the Turkish context, the eastern location of Erzurum is not anecdotal with respect to the socio-demographic and economic inequalities across the country. Relative to the Aegean and Mediterranean cities, the socio-demographic and economic profile of the province of Erzurum combines characteristics of Turkey's southeastern peripheries: a place of out-migration explained by under-representation of industrial employment, employment in the services sector and educational opportunities and an under-representation of agriculture (Yazgi et al., 2014), aggravated by the process of globalisation and liberalisation since the 1990s and the failure of regional policies at national level in the 1980s (Ibid.). This dimension of economic periphery is also sensible in 
the student population of the survey. A statistical test (Chi-Square) confirms the presence in Erzurum of students declaring lowest level of income and less declaring highest levels of income than in Istanbul. There is no significant difference between Erzurum and Izmir.

This peripheral city is also less connected than the western metropolis to the "global megapolitan archipelago" (Dollfus, 2007) and the European pole. In addition, and mainly because of this peripheral situation, the University of Erzurum (Attatürk Üniversitesi) seems to be less attractive ${ }^{24}$ according to students than universities in Istanbul ${ }^{25}$ or Izmir $^{26}$ . Even if we can easily characterize Erzurum as a periphery of the Turkish territory and university system, it could not authorize us to conclude that this place is able to harbour a more "traditional" or "conservative" vision of the world. Despite this last point, we observe that the students of Erzurum are producing a more eastern-oriented vision of the world, compatible with an historical interpretation. For instance a specificity of Erzurum's students is to see Azerbaijan more positively and less negatively than the students of Istanbul and Izmir. According to History, the links between these "Turkish republics" and Turkey have been emphasised in recent history by left radical nationalism (Copeaux, 1992; 1994; 1996), a growing identity reference to these places as the centre of gravity of the original Turkish culture and language. In the same way the "prosovereignty" attitude in Turkey (which is not necessarily nationalist or conservative, Yerasimos 2005) tends to consider the historical construction of the Turkish state as an anti-imperialist cause against the historical Western imperialist powers (Akçali et al., $2009)^{27}$ and their allies (such as Israel in the results for Erzurum).

These elements based on the knowledge of the use of Turkish history and historiography in official and political discourse (and its percolation into the teaching of history in schools), may explain the repulsion for countries like Greece or Armenia (the "old enemies" of Turkey) and even Israel. This contextualisation may also explain the less "unattractive" vision of Afghanistan. Seen from Erzurum, Afghanistan is remote from Turkey, without sharing strong relations, unlike countries with serious difficulties like Iraq.

However, these negative mentions relating to the city's context show a kind of geohistorical and geopolitical interpretation of the world in Erzurum, through the designation of countries sharing a history of conflict with Turkey (like Armenia, Greece and Russia) or actors in the regional context (Israel, Russia). We are in a sense confronted with a conventional vision of the world focused on "old enemies of Turkey".

The case of Russia as a specific negative country as seen by Erzurum's students may also emphasises the condition of Erzurum as a city historically close to the border with a strong military presence. Erzurum was a regular battlefield and occupied city during the Russo-Ottoman wars (the city was occupied by the Russian army in 1829, 1877-78 and 1916-1918) commemorated by impressive memorials in the centre of the city (Erzurum Özgürlük Anttı). It was also a centre of the Armenian Genocide during the World War I. Nor should we forget that until 1991 (the students in the survey were born around 1987) Erzurum was the most Eastern NATO base facing the USSR border. The military presence is still considerable in the city of Erzurum (military housing, offices and soldiers). In a sense the negative representations of Russia in Erzurum could be related to the memories of war in the city.

This situation is very different from Izmir, where Russia is more positively viewed, since it is perceived through the numerous Russian tourists coming to the cities located on the Aegean and Mediterranean coasts of Turkey. Those interactions with Russian people ${ }^{28}$ 
through less negatively connoted forms of relations (tourist, economic) may produce a less traumatic background in terms of memories.

These elements of contextualisation are of course interpretations of the global results for this city, but it is quite difficult to conclude about the specific role of historical local factors or socio-economic situation in the making of Erzurum student's representations.

\section{A more nuanced analysis introducing gender}

This first attempt of making geography of representations can be highly ameliorated by observing separately female from male students, which is in fact the main explicative factor of the world perception. Thus, the geography drawn by the representations is quite opposed. The specific quotations of female students in terms of attractive and positive countries are represented below following the same principia than the precedent figure.

Figure 5. Attractive and unattractive countries according to gender.

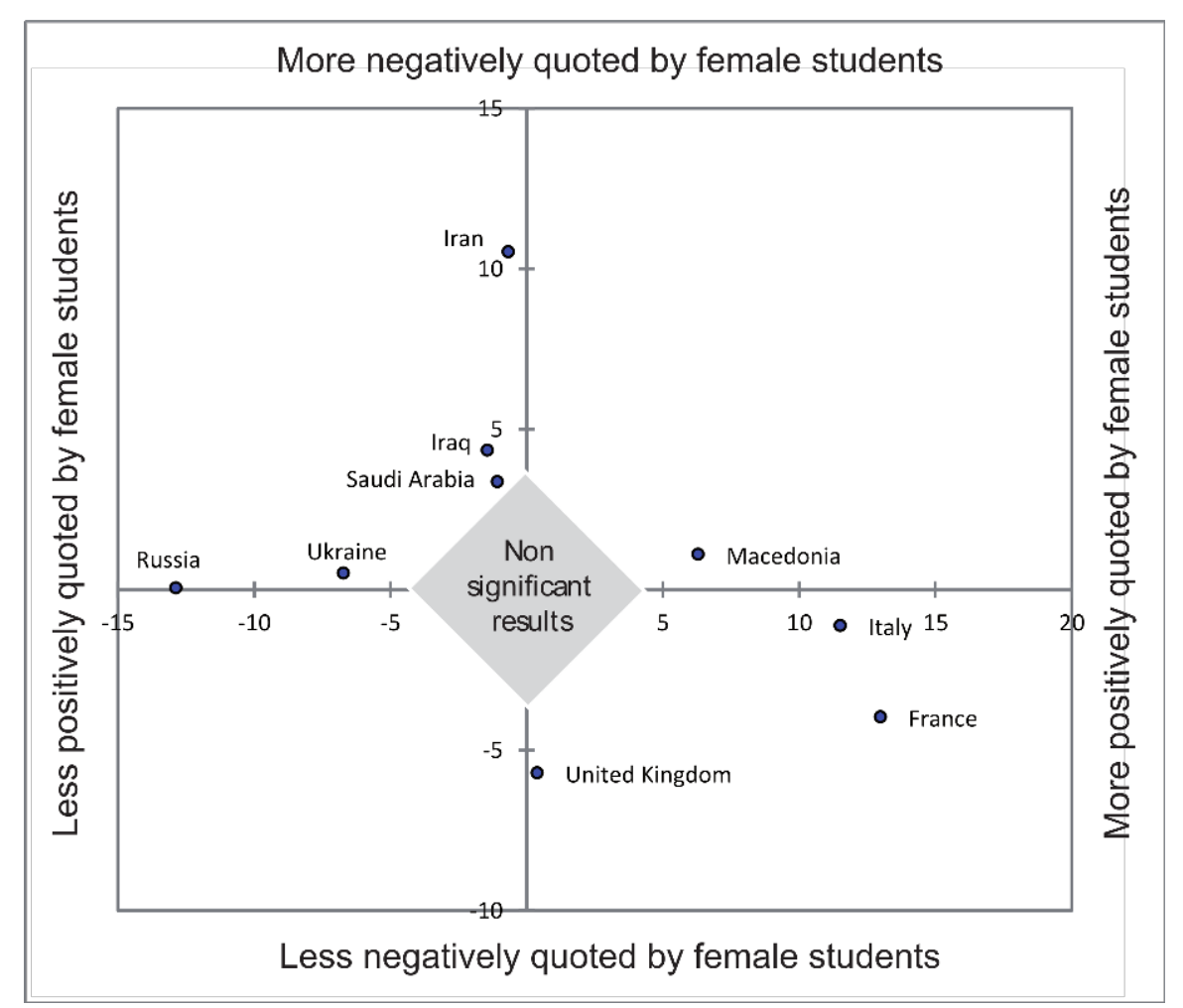

SOURCE: EUROBROADMAP, 2009

We observe another opposition between Eastern and Western countries. Female students tend more often to cite Iran, Iraq and Saudi Arabia as countries where they would not like to live and countries like France, Italy and Macedonia as places where they would like to live. Reluctance about Iran, Iraq and Saudi Arabia is easily understandable because of the images of women's rights and living conditions in these countries, compared to Turkey. The case of the countries more positively cited by women is rather more complex. Italy and Macedonia are more consensual choices for women and when they are negatively mentioned, it is not significantly different from men. However, France is at the same time more positively and less negatively quoted by women, denoting a strong divergence of appreciation between men and women. The United Kingdom has another profile: less 
often mentioned negatively by women but in same proportion as men in a positive way. Finally, these young educated women are more attracted by western European countries and Macedonia, especially the major tourist destinations (France, Italy, and UK). We may also suggest that this attraction is the result of the weak attraction of some Eastern countries like Russia and Ukraine for instance which are on the other hand very attractive for male students.

\section{A wider vision of the world from social sciences students...}

Beyond this gender effect, we have noticed the effect of the field of study on the choice of countries (Brennetot et al., 2013), especially for students in the social sciences ${ }^{29}$. Among the different disciplines, they show much more varied choices whether in positive or negative terms (Fig. 5).

Figure 5. Attractive and unattractive countries for social sciences students

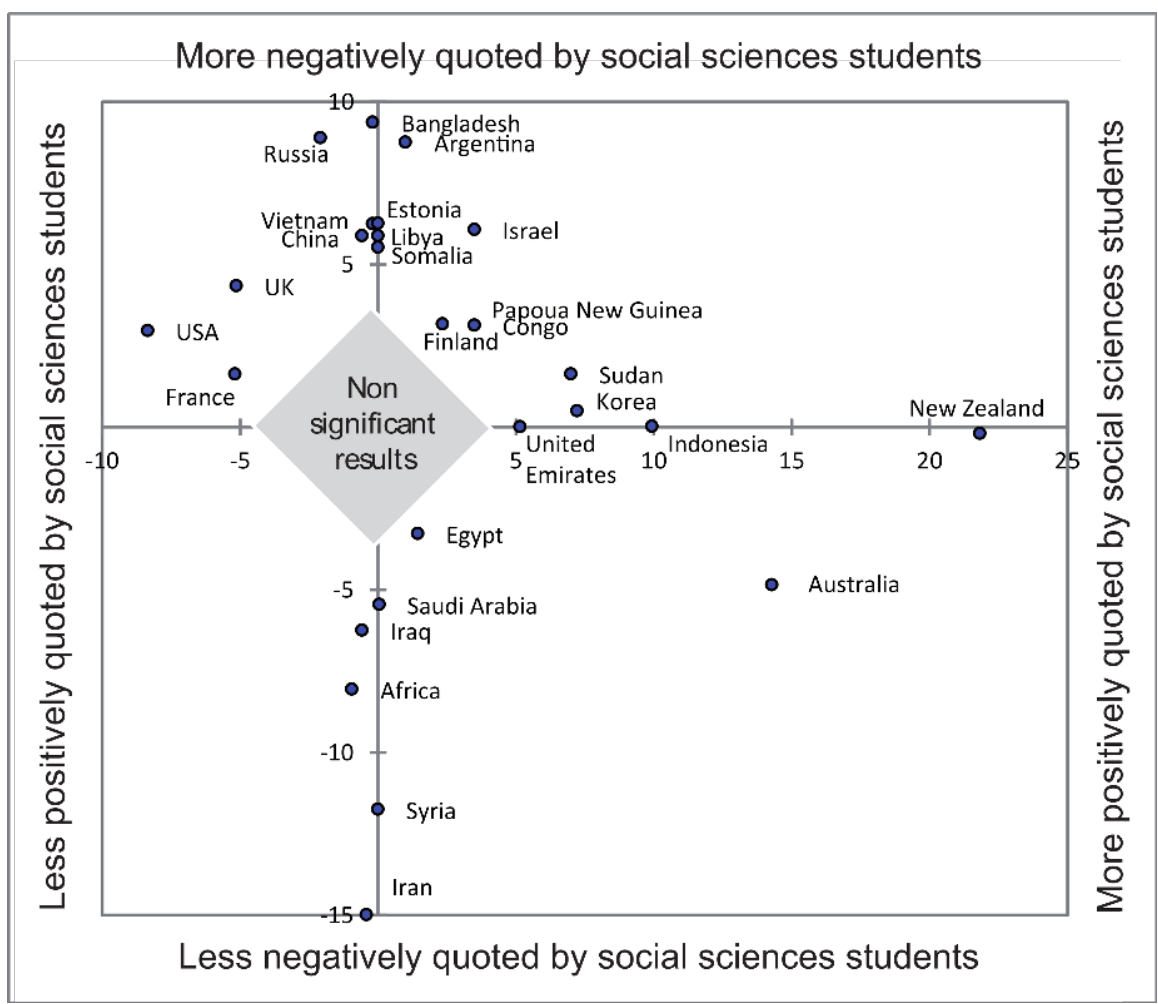

SOURCE: EUROBROADMAP SURVEY, 2009.

First, we find a group of countries which are less negatively viewed than in the dominant representations (Iran, Syria, Saudi Arabia - see Fig. 2) while countries which are usually quoted positively (UK, France, USA) are cited less positively by social sciences students.

At the same time they mention less "known" countries more positively than students from other fields of study (New Zealand, Australia, Indonesia, Korea and United Emirates). Mostly, these countries are old regional economic powers, like New Zealand and Australia but we also find some emerging countries like the United Emirates. All of them are also relatively remote from Turkey in terms of geographical distance. 

Council (Russia, United Kingdom, USA and France). These countries have in common that they are mentioned more often negatively and less positively than by students of other disciplines. We might again propose interpretations relating to their education as students of geography. As a consequence of being more attracted by new regional powers and as people informed about new configurations in the world, these old centres may seem less attractive for them and at the same time, those students are more able to develop a kind of critical geopolitical approach. By perceiving these old global powers less positively they may be describing an anti-imperialist geography from the Turkish point of view (see above), in connection with the way of teaching history and geography, for a group of individuals who are mostly going to become teachers in secondary schools. Furthermore, taking into consideration the historical involvement of these powers in the Middle East and Central Asia may explain the tendency of geography students to mention those countries negatively (in recent history during the Cold War and US and Russian interventions, or in the past with the game of European powers after the collapse of the Ottoman Empire). These hypotheses reflect their specific choices as attractive countries. Indeed, they are positively mentioning remote countries less charged in terms of geopolitical influence within the Turkish neighbourhood. This may partly explains the fact that Israel is more often mentioned negatively by geography students but at the same time slightly more often mentioned positively.

68 A final hypothesis may be put forward to explain why students in geography are less often mentioning European countries positively in relation with their awareness of issues of regional integration. Therefore they are maybe more reactive due to their disappointment concerning the non-admission of Turkey to the European Union and therefore have a vision of the world based on new strategic alternatives for Turkey. This particular situation of students in geography may cause them to develop a kind of "looking-glass rejection" of Europe (Yerasimos, Ibid.), seen in their mentions of Eastern or Asian countries, producing an oriented vision of the world.

\section{Conclusion}

Relating all these points to the background of students in terms of academic courses supports the conclusions developed by Saarinen (Saarinen 1987), who explained the "centring" of mental mapping (the distortion of the representations) by the individual's knowledge, which is itself strongly influenced by the national context (especially education). 
weography studied here through the vision of Turkish students of attractive or unattractive places for living confirms to a large extent the results of the Eurobroadmap survey for other countries. Some of the global explanations are still relevant in the Turkish context, especially concerning the influence of the proximity factor in the citation process, whether for unattractive or attractive countries (size of the divergence of the Erzurum representation from that of Istanbul and Izmir). But other factors than the location of the observer seems to play an important role such as gender and field of study. Moreover, a large part of these representations is affected by the complex question of the relations between Turkey and conceptual entities like "West", "East", as a key for understanding the structure of the representations.

71 attractive countries to live, or which describes Western powers as unattractive, we observe that most European countries (especially through the representation of western and southern European countries like Italy, France, Britain and Spain), were still very positively viewed by Turkish students in 2009-2010 and constitute a structuring pole for their representations of the world.

\section{BIBLIOGRAPHY}

ACA (2004), Perceptions of European Higher Education in Third Countries, 7 p. URL: http://

ec.europa.eu/education/programmes/mundus/doc/acasummary.pdf.

AKÇALI E., PERINÇEK M. (2009), “Kemalist Eurasianism: An Emerging Geopolitical Discourse in Turkey", Geopolitics, 14, Routledge, pp.550-569.

AKGÖNÜL S. (2001), “Vers une nouvelle donne dans les relations gréco-turques?”, Les Dossiers de l'IFEA, série: “La Turquie Aujourd'hui”, avril 2001, n6, Istanbul, Institut Français des Etudes Anatoliennes (IFEA), $46 \mathrm{p}$.

ARTIK Ö. (2013), “La Turquie: retour au Moyen-Orient”, Hérodote, 148, La découverte, pp. 33-46.

BAZIN M. (1995), "La Turquie, le modèle unitaire en question”, in DURAND-DASTÈS F., MUTIN G. (eds.), Afrique du Nord, Moyen-Orient, Monde indien, Paris, Belin-GIP Reclus, pp. 202-219.

BAZIN M., KANÇAL S., PEREZ R., THOBIE J. (eds.) (2000), La Turquie entre trois mondes: actes du colloque international de Montpellier, 5, 6 et 7 octobre 1995, Paris, L'Harmattan.

BAZIN M., de TAPIA S. (2012), La Turquie: Géographie d'une puissance émergente, Paris, Armand Colin. BEHAR C. (2002), “Une Transition démographique presque achevée: la Turquie”, in CHASTELAND J.C., CHESNAIS J.C. (eds.), Cahiers de l'INED: La population du Monde, Géants démographiques et défis internationaux, 149, Paris, Institut National des Etudes Démographiques, pp. 405-416.

BENNASR A., GRASLAND C. (2011), "Le 'petit monde’ des géographes. Analyse des cartes mentales des pays du monde de 140 géographes présents au congrès UGI de Tunis en 2008”, EchoGéo, 18. 
BRENNETOT A., EMSELLEM K., GUÉRIN-PACE F., GARNIER B. (2013), “Dire l'Europe à travers le monde”, Cybergeo: European Journal of Geography, Politique, Culture, Représentations, article 630, http://cybergeo.revues.org/25684.

CHABAN N., HOLLAND M. (2014), Communicating Europe in times of crisis: External perceptions of the European Union, Palgrave Macmillan.

COPEAUX E. (1992), “Le rêve du Loup Gris”, Hérodote, 64, pp. 183-193.

COPEAUX E. (1994), "L'Invention de l'Histoire", in YERASIMOS S. (ed.), Les Turcs - Orient et Occident, Islam et Laïcité, Paris, Autrement, pp. 160-176.

COPEAUX E. (1996), Espaces et temps de la nation turque: analyse d'une historiographie nationaliste, 1931-1993, Paris, CNRS éditions.

COPEAUX E. (2000), Une vision turque du monde: à travers les cartes de 1931 à nos jours, Paris, CNRS éditions.

DIDELON-LOISEAU C., GRASLAND C. (2014), "Internal and external perceptions of Europe/EU in the world through mental maps", Communicating Europe in times of crisis: External perceptions of the European Union, pp. 65-94.

DIDELON C., DE RUFFRAY S., GRASLAND C. (2011), "Volume 2: Introduction”, Cross Country Synthesis on Survey (deliverable 2.6 of the Eurobroadmap survey), Dec. 22, 2011, pp. 34-59.

DOLLFUS O. (2007), La Mondialisation, Paris, Presses de Science Po.

DORTIER J.-F. (2002), “L'univers des représentations ou l'imaginaire de la grenouille”, Sciences humaines, 128, juin 2002, pp. 24-31.

EMEÇ H., BİNGOL P., KUMBUL-GÜLER B., ZENGINGÖNÜL Ö., KIRKPINAR-ACAR N. (2011), "Comparative Geographical Perception of World Analysis Between Turkish and Azerbaijani Students", Europe seen from here and elsewhere, proceedings of the concluding event of FP7 project EuroBroadMap - Vision of Europe in the World, Rouen, $1^{\text {st }}-2^{\text {nd }}$ December 2011, 5 p.

GOULD P., WHITE R. (1974), Mental maps, Boston, London, Sydney, Allen and Unwin.

GRASLAND C., SAINT-JULIEN T., GIRAUD T., BEAUGUITTE L. (2011), "Mental maps of students Volume 4", Cross Country Synthesis on Survey (deliverable 2.6 of the Eurobroadmap survey), Dec. 22, 2011, pp. 90-134.

GRASLAND C. (coord.) (2011), Country Synthesis Report, FP7 Eurobroadmap project, 232 p., available at http://www.ums-riate.fr/mapper/pdf/COUNTRY_SYNTHESIS_full.pdf

GROC G. (2001), "Une Nouvelle diplomatie turque. Présentation critique de la doctrine Davutoğlu à partir de son livre, Profondeur stratégique, et de quelques autres textes", Policy Paper, 8 décembre 2011, Paris, Institut de Relations Internationales et Stratégiques, 28 p., http://www.irisfrance.org/docs/kfm_docs/docs/observatoire-turquie/2011-12-08-grard-groc---nouvelle-diploturque.pdf.

GUÉRIN-PACE F. (1998), “Textual statitics. An exploratory tool for the social sciences”, Population : An English Selection, Paris, Institut National d’Etudes Démographiques, pp. 73-95.

GUÉRIN-PACE F. (2006a), “Sentiment d'appartenance et territoires identitaires”, L'Espace Géographique, 345, 4, Paris, Belin, pp. 298-308.

GUÉRIN-PACE F. (2006b), “Lieux habités, lieux investis: le lien au territoire, une composante identitaire?", 2006, Economie et statistique, 393-394, pp.101-114. 
HENSEL P.R., DIEHL P.F. (1994), “Testing empirical propositions about shatterbelts”, Political Geography, 13, 1, pp. 33-51.

JESSOP B., BRENNER N., JONES M. (2008), “Theorizing sociospatial relations”, Environment and planning. D, Society and space, 26,3 , pp. 389-401.

KIRKPINAR-ACAR N., EMEÇ H., ZENGINGÖNÜL O., GÜLER B. (2011), EuroBroadMap Country Synthesis Report: Turkey, Intermediate report of FP7 EuroBroadMap Project, 20 p., available on the web in the "Subjective Mapper", http://www.ums-riate.fr/mapper/pdf/COUNTRY_SYNTHESIS_tur.pdf.

KOLOSSOV V. (2013), "The vision of Europe and the world as seen by large powers: the case of the BRIC countries”, Geographia Polonica, 86, 2, pp. 89-98.

LYNCH K. (1960), The image of the city, Cambridge and London, MIT Press.

HÜTTENROTH W.D. (1982), Türkei, Darmstadt, Wissenschaftliche Buchgesellschaft.

MOLES A.A., ROHMER-MOLES E. (1972), Psychologie de l'espace, Paris, Casterman.

NAHAVANDI F. (ed.) (2012), Turquie. Le déploiement stratégique, Paris, Bruylant.

REY V. (1994), “Transition, Fragmentation, Recomposition, à propos de la Tchéco-Slovaquie, du verdict des élements à des problématiques géographiques, in REY V. (ed.), Transition,

Fragmentation, recomposition, la Tchéco-Slovaquie en 1992, pp. 7-23.

RIATE (2011), Subjective Mapper, Interactive Atlas of results of the FP7 Eurobroadmap project, realized and hosted by UMS 2414 RIATE, http://www.ums-riate.fr/mapper/

ROBINS P. (2007), “Turkish foreign policy since 2002: between a 'post-Islamist' government and a Kemalist state", International Affairs, 83, 1.

SAARINEN T.F. (1987), Centering of mental maps of the world. Discussion Paper, Tucson, Department of geography and regional development.

SAARINEN T.F., MACCABE C. (1995), "World patterns of geographic literacy based on sketch map quality”, The professional geographer, 47, pp. 196-204.

YAZGI B., DÖKMECI V., KORAMAZ K., KIROĞLU G. (2014), "Impact of Characteristics of Origin and Destination Provinces on Migration: 1995-2000”, European Planning Studies, 22, 6, pp. 1182-1198.

YERASIMOS S. (2005), “L’Europe vue de la Turquie”, Hérodote, 118, 3, pp. 68-81.

WALLERSTEIN I. (2009), Comprendre le monde. Introduction à l'analyse des systèmes-monde, Paris, La Découverte.

\section{NOTES}

1. Each national report was designed according to a very strict template, in order to propose an interactive atlas available on the internet, called Subjective Mapper (RIATE, 2011).

2. The question was "In which countries would you like to live (not like) in the near future?"

3. Source: World Bank, 2010.

4. Source: Türkstat, 2013.

5. Born in 1959, he is originally Professor of International Affairs and seen as the theorist of the AKP foreign policy. He became the advisor in foreign affairs of Prime Ministers Abdüllah Gül (from February 16, 2002 to March 9, 2003) and Recep Tayyip Erdoğan (March 29, 2003 to May 1, 2009), before being the foreign minister of Recep Tayyip Erdoğan's administration (from May 1 , 
2009 to August 28, 2014), and finally Erdoğan's Prime Minister after his accession to the presidency (since August 29, 2014).

6. The questionnaire was given out by the class tutor. The time to fill it in was 15 minutes maximum.

7. A footnote specified that your "own" country is the country for which you currently have the nationality written in your passport.

8. A maximum of 5 places was allowed for each answer.

9. We collected information about age, gender, nationality, places of residence, languages spoken, evaluation of family income and parents' education level.

10. Turkish students' international mobility indicators are relatively low (Didelon et al. 2011).

11. Türkstat (National Institute of Statistics in Turkey), 2010.

12. Türkstat 2011.

13. Türkstat, 2011.

14. For more information see: www.EuroBroadMapoadmap.eu

15. The indicator varies from -1 (all country's mentions are negative), 0 (equality between negative and positive answers) to 1 (all positive).

16. Some semi-directive interviews were conducted in Turkey by Etienne Toureille in the context of his PhD.

17. The economic crisis was still in its beginning in 2009 and its development was not predictable.

18. The Mavi Marmara was one of the ships belonging to the Gaza fleet raid in July 2010. It was intercepted by Israeli forces leading to a violent clash causing several deaths. This event raised tensions between the two countries after a gradual degradation of relations since the rise to power of the AKP in Turkey in 2002

19. The publication of caricatures of the Prophet Mohammad in a Danish newspaper was at the origin of a massive polemic around the world, which impacted the Muslim communities, and also a large part of religious people and believers in Turkey.

20. A multiple correspondence analysis was conducted on positive and negative mentions with a set of individual characteristics.

21. We used two different statistical tests (chi-squared) for the positive and for the negative mentions.

22. According to the results of the AFC.

23. Some elements are taken from interviews conducted with students, by Etienne Toureille during his PhD. research.

24. According to the interviews conducted by Etienne Toureille during his $\mathrm{PhD}$. research.

25. Istanbul University, except for students in the Health sector (Yeditepe University), in Art and Engineering (Işık University).

26. Dokuz Eylül University, except for students in Art (Ege University) and some students in the Health sector.

27. The War of Independence (1919-1923), led by Mustapha Kemal and the founding point of the Kemalist state ideology for the new Turkish Republic, was waged against the instigators of the Treaty of Sèvres (France and Britain).

28. During the interviews, some students declared that they had summer jobs in seaside cities.

29. We must specify that the social sciences students who were surveyed were all geography students. 


\section{ABSTRACTS}

The recent history of Turkey is characterised by major changes in public discourse and public opinion, related to the changing position of Turkey on the world stage. Changing attitudes toward European Union appear to be a marker of this transformation.

The aim of this paper is to evaluate the perception of Europe and the world in the eyes of Turkish undergraduate students through a secondary analysis of a worldwide survey carried out in 2009-2010 by the FP7 EuroBroadmap project. The paper proposes first to test the hypothesis of a polarisation of Turkish representation by the European Union against the alternative hypothesis of a dual vision of Europe related to the ambiguity of Turkey's situation. This part concludes that western and south European countries (like Italy, France, Britain and Spain), were still very positively viewed by Turkish students in 2009 and constitute a structuring pole of their worldwide representations. But the paper also examines variations in these average mental maps according to individual parameters. This second analysis reveals huge internal variations, according to place, gender and field of study and confirms that visions of the world held by students in this country are neither trivial nor consensual.

La place de la Turquie sur la scène internationale a connu de profonds changements dans l'histoire récente, tant dans le discours des acteurs qu'au sein de l'opinion publique. L'évolution des attitudes vis-à-vis de l'Union Européenne constitue un indicateur pertinent de ces transformations.

L'objectif de cet article est d'analyser la perception de l'Europe et du Monde du point de vue des étudiants turcs dans l'enseignement supérieur, à travers une analyse rétrospective d'une enquête internationale menée en 2009-2010 dans le cadre du projet FP7 EuroBroadmap. Dans un premier temps, nous testerons l'hypothèse d'une polarisation des représentations turques par l'UE contre l'hypothèse alternative d'une vision ambivalente de l'Europe, liée à la situation ambiguë de la Turquie vis-à-vis de cette dernière. Cette première partie montre que les pays d'Europe occidentale et méridionale (comme l'Italie, la France, la Grande Bretagne ou l'Espagne) restent perçus comme des destinations très attractives par ces étudiants en 2009, et constituent des pôles structurants de leurs représentations du Monde. En outre, l'article propose de dépasser une analyse globale pour examiner plus en profondeur la variation de ces représentations en fonction des caractéristiques individuelles des enquêtés. Cette seconde analyse montre d'importantes variations à l'intérieur de la population étudiante, selon le lieu de formation, le sexe et la discipline d'étude. Ce dernier point confirme l'idée selon laquelle les représentations du monde des étudiants turcs ne sont ni triviales, ni consensuelles.

\section{INDEX}

Mots-clés: géographie, sciences politiques, représentations, cartes mentales, étudiants, Turquie, Europe, Union européenne, Monde, États

Keywords: geography, political science, representation, mental maps, students, Turkey, European Union, world, cities, states, push-pull 


\section{AUTHORS}

\section{FRANCE GUÉRIN-PACE}

Ined, Paris, guerin@ined.fr

\section{ETIENNE TOUREILLE}

Université Paris-Diderot,etienne.toureille@gmail.com

\section{CLAUDE GRASLAND}

Université Paris-Diderot, claude.grasland@parisgeo.cnrs.fr 